\title{
EN TORNO A LOS ORÍGENES SOCIALES Y LAS ESTRATEGIAS DE EMIGRACIÓN: EL CASO DE LOS LEONESES EN LA CAMPAÑA SUR DE BUENOS AIRES (1900-1930)
}

POR

BLANCA ZEBERIO

Universidad de Tandil. Argentina

\section{INTRODUCCIÓN}

Este artículo nace de una serie de interrogantes que nos hemos planteado a partir de un estudio sobre la inserción en el medio rural y el acceso a la producción agraria de inmigrantes europeos (principalmente españoles) en el sur de la provincia de Buenos Aires. Una conclusión evidente se desprendía de aquel análisis: más allá del grado de "éxito" relativo obtenido por cada comunidad de inmigrantes: estos hombres habian alcanzado una gran capacidad de adaptación y un rápido conocimiento de las reglas de juego del sistema. Sin dejar de lado la fuerte influencia de la sociedad de destino - caracterizada en este caso, por una relativa abundancia de tierra, excelentes condiciones ecológicas para la producción de cereal y la necesidad imperiosa de brazos para ponerlas en producción- no podemos desdeñar el rol personal jugado por cada uno de estos pequeños productores, a mitad de camino entre un empresario y un productor familiar, que entremezclaban con acertada habilidad racionalidad económica, ahorro y trabajo familiar.

Estos productores, que mostraron una gran maleabilidad y capacidad de adaptación a las reglas de juego del sistema -lo que en buen romance quiere decir un certero olfato para detectar

Agradezco sinceramente los comentarios y sugerencias recibidas de M. Bjerg, H. Otero y M. Iriani. 
las oportunidades y los potenciales negocios, que le permitían hacerse con un capital o un ahorro- llegaron a despertar nuestra sorpresa y hasta admiración; constatación que llevó a replantearnos las visiones históricas esbozadas por ciertos sectores políticos e intelectuales y luego trasladadas con mayor o menor intensidad a la historiografía, de un inmigrante analfabeto, rústico, conservador y víctima de todo tipo de explotaciones y engaños.

Éste fue, por cierto, el punto de partida para intentar adentrarnos en una cuestión harto compleja pero sumamente atractiva: tratar de hurgar en el pasado y origenes sociales de estos hombres asentados en la Pampa. Abordar esta problemática nos permitirá encontrar, creemos, una nueva vía para el estudio de los comportamientos y estrategias de los emigrantes en la sociedad de destino. Un conjunto de preguntas iban apareciendo en nuestra mente, a medida que reflexionábamos sobre la cuestión: ¿Se trataba de migrantes provenientes de los sectores más sumergidos de la sociedad española? ¿Eran los más humildes los que estaban en condiciones de tomar la decisión tanto material como psicológica de emigrar, para buscar mejores posibilidades de vida? ¿Existía alguna relación entre los orígenes regionales de estos productores agrícolas y un tipo de emigración más o menos calificada?

Asimismo, trataremos de abordar el fenómeno migratorioinmigratorio, como parte de las estrategias de una economía campesina que buscaba como alternativa a su supervivencia la salida de algunos de sus miembros. El acto de emigrar iSe trataba de una acción individual o formó parte de una estrategia familiar o colectiva? ¿La acción en las nuevas tierras cuánto de esa estrategia reflejaban? En otro plano, ¿cuánto de reproducción de sus viejas conductas o cuánto de nuevos comportamientos, implicaba la adaptación a la nueva realidad? El bagaje de experiencias que poseían algunos, ¿les servía como referente frente a la nueva acción?

Este conglomerado de interrogantes, que nos preocupan, los ceñiremos a una realidad puntualizada desde el punto vista espacial: la campaña sur de Buenos Aires y a los productores de origen leonés y vasco, tanto en relación a sus condiciones de emigración, como a su inserción en la sociedad de destino. Si bien nuestro estudio puede pecar de excesivo microanálisis $-\mathrm{y}$ somos plenamente conscientes de ello-, creemos que al visualizar el fenómeno de la emigración desde una perspectiva micro y al tratar de hurgar en el pasado social, laboral e incluso cultural de 
estos actores, será mucho mas fácil explicarnos al menos algunas conductas de estos hombres en la sociedad "receptora». Dentro de la historiografía argentina, las vías o posibilidades de éxito del inmigrante $-y$ por tanto de ascenso social- son una preocupación central, profundizar en los origenes, aptitudes y potencialidades del emigrante desde su país de origen, es una perspectiva que podría echar nueva luz sobre la cuestión, completando así, la visión tal vez demasiado centrada sobre las condiciones de la "sociedad receptora" que existe actualmente.

En síntesis, nuestra démarche será en parte el revés: partiremos de la sociedad de destino, los españoles en la campaña pampeana, para luego intentar rastrear en relación al caso leonés -lamentablemente carecemos el mismo nivel de información para los vascos-, las "causas" de salida, los orígenes sociales y ocupacionales y las estrategias de emigración. Una de las ventajas que tenemos los historiadores frente a otros cientistas sociales es conocer de antemano el "final" de la historia, por lo tanto nos es posible, al igual que en las películas retrospectivas, introducirnos en la trama en un momento determinado y reconstruir un poco a nuestro albedrío, la vida de los actores hacia atrás o hacia adelante.

Hemos organizado nuestro trabajo en dos partes principales:

1) Una presentación de la sociedad de destino y de los principales grupos de origen español que se transformaron en productores rurales en el sur de la provincia de Buenos Aires.

2) A partir de documentación localizada en Archivos de León plantearemos algunos avances respecto de: causas de emigración, origen de los emigrantes y estrategias familiares de emigración.

1. Migración española y asentamiento RuRal EN El SuR DE BUENOS AIRES

La Región Sur (campaña y poblados) experimentó desde fines del siglo XIX, una profunda transformación de la estructura productiva y demográfica, debida en gran parte a la presencia de inmigración europea. Este fenómeno conllevó la extranjerización de la pirámide poblacional y la aparición de nuevas capas sociales. De una sociedad fuertemente dualizada - en dos sectores estancieros y peones y con predominio de actividades pecuarias- se fue pasando a otra más diversificada y compleja, donde la presencia creciente de pobladores europeos - que engrosaron en su 
mayoría los estratos medios-, facilitaron la aparición de nuevos sectores productivos vinculados al comercio y servicios. Este proceso, con todos sus matices y fluctuaciones se prolongó desde las dos ultimas décadas del siglo pasado hasta los años 1920. Si bien dicho proceso, presentó en líneas generales características semejantes al poblamiento de otras zonas mas antiguas dentro de la Provincia y del Litoral, los partidos del Sur manifestaron una presencia española mas pronunciada respecto de otras zonas en las que la comunidad italiana fue mayoritaria (1). El grupo español mostraba, a diferencia de lo que se sostenía tradicionalmente, una significativa presencia en los diferentes escalones ocupacionales del trabajo rural (peones, jornaleros, aparceros, arrendatarios) (2).

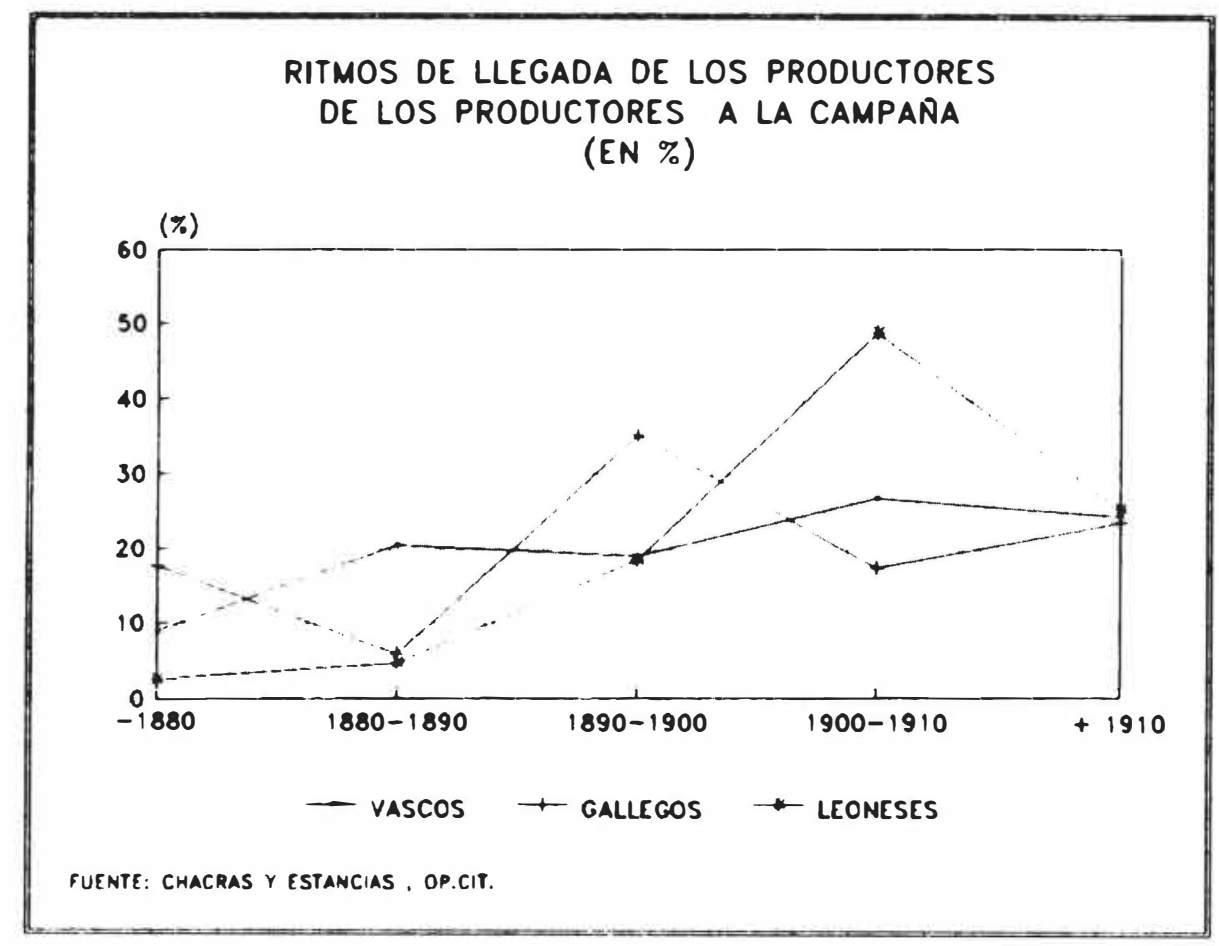

Gráfico 1

Los datos de la estructura socio-ocupacional confirman esta preferencia española por los medios rurales. Por ejemplo en

(1) Además, otro rasgo distintivo de estas zonas, fue la presencia de grupos de alta cohesión social como la colonia danesa, de rusos blancos y holandesa, cuya presencia no es tan significativa en otras zonas más tradicionales.

(2) Este tema lo hemos desarrollado más detalladamente en "La utopía de la tierra en el nuevo sud" en Anuario IHES, (Publicación de la Universidad Nacional del Centro de la Provincia de Buenos Aires), nº 6, 1991, págs. 81-112. 
Tandil, hacia fines de siglo, los españoles representaban un porcentaje elevado de la mano de obra rural, los jornaleros y peones representaban $27,4 \%$ de los casos y los especializados rurales (alambradores, poceros, herreros, etc.), el 21,09\%, los pequeños productores rurales el 16,9\% y los empresarios ganaderos y rentistas 23,3\% del total de españoles los ocupados. En cambio, los italianos mostraban una mayor preferencia por las actividades ruri-urbanas, un 50,1\% de los italianos residentes trabajaban en relación con el comercio y servicios. También fue muy importante su presencia como pequeños granjeros en las zonas ejidales de los pueblos (3).

Esta significativa presencia de españoles, es atribuible a la coincidencia histórica entre la más tardía inserción de estas tierras en el mercado y la llegada masiva de españoles hacia principios del siglo XX. Esta feliz coincidencia, implicó una verdadera españolización del mundo rural de los partidos del sur bonaerense. Hacia 1914 según el Censo Nacional de poblacion, alrededor del $70 \%$ de los productores rurales de los partidos del sur bonaerense, eran inmigrantes provenientes de ultramar, con predominio de dos comunidades, españoles e italianos. Quince años después, hacia 1930, no se habían producido grandes modificaciones, la presencia de extranjeros había disminuído sólo un $10 \%$. Esta disminución, se explica por el recambio generacional de los responsables de las explotaciones y por la desaceleración del ritmo de asentamiento de extranjeros, reafirmamos lo de desaceleración puesto que la segunda parte de la década del '10 y parte de los años '20, registró una fuerte movilidad poblacional ademas de la emergencia de un "nuevo" sector de productores rurales (4). De acuerdo a los datos del Relevamiento de chacras y estancias

(3) Cabe aclarar que cuando hablamos de medios rurales, nos referimos tanto a la campaña propiamente dicha -es decir, pobladores que vivían en sus explotaciones 0 en el seno de las estancias que podian llegar a ser verdaderos poblados - a las pequeñas comunidades ruri-urbanas (colonias agrícolas, estaciones de ferrocarril) que se fueron creando hacia fines de siglo y que satisfacían las necesidades mínimas de esa población rural. Ver N. Álvarez y E. Míguez ( "Estructura socio-ocupacional de Tandil, 1869-1895", Actas de las Cuartas Jornadas de Historia Económica, Córdoba, 1984.

(4) Las conclusiones obtenidas respecto de la presencia española en el medio rural, así como los datos sobre acceso a la propiedad, los hemos extraído de una Base de Datos realizada sobre 1.774 casos de productores agrarios de los partidos de Necochea y Tres arroyos, realizada a partir del Relevamiento de chacras y estancias, Edit Kraft, Buenos Aires, 1930-1931. Además hemos utilizado diversas publicaciones que recogian las historias de vida de inmigrantes tales como: Revista Vida Agraria, varios números de 1928, El álbum de los españoles en el Centenario de la Bahia Blanca, Bahía Blanca, Buenos Aires, segunda edición, 1928. 
(1930), la comunidad española representaba alrededor del $20 \%$ de los casos de productores agrarios y estaba conformada en lo que a orígenes regionales se refiere, por dos grupos principales: los vascos (provincias vascas y Navarra), que representaban el $35.4 \%$, en segundo lugar los provenientes de Castilla la Vieja $34,5 \%$ (de los cuales los leoneses eran más del $80 \%$ de los casos). Con importancia menor también se encuentran los asturianos $(4,1)$ gallegos $(7,9)$ y andaluces $(5,1)$.

Esta presencia mayoritaria de vascos y leoneses en la campaña sur se debía, además de la existencia de ciertas condiciones en la sociedad de salida, como veremos luego, a la existencia de una red de paisanos que sirvieron de nexo para la radicación de nuevos pobladores. Los vascos habían logrado constituir desde mediados del siglo XIX una red informal que se extendía desde los partidos de más antigua colonización (Lobos, Pergamino, Chascomús, etc.) hacia las zonas de nueva colonización y que facilitaba la instalación e inserción de los recién llegados en las actividades agropecuarias. En relación a los leoneses, esta red informal se había construído más recientemente y tenía como sede de "operación» la ciudad de Bahía Blanca, donde se iban instalando los productores que habían alcanzado cierta posición. Los campesinos leoneses salían de sus aldeas hacia el Río de la Plata y se dirigían directamente hacia los partidos cerealeros del sur; allí les esperaba un trabajo como jornalero, pequeño arrendatario o aparcero, punto de partida para iniciar el duro camino del ascenso social.

$\mathrm{Si}$ bien las posibilidades de enriquecimiento a través de la actividad agrícola fueron relativamente buenas durante estas tres primeras décadas del siglo $\mathrm{XX}$, no todos corrieron igual suerte ni ensayaron las mismas estrategias para llegar a la meta. Como se desprende del gráfico $\mathrm{n}^{\mathfrak{2}} 2$, existía, según los orígenes regionales de los productores, una cierta estratificación en el tipo de explotaciones organizadas. Los gallegos desarrollaron explotaciones de pequeña dimensión más del $60 \%$ de los casos se localizaban en parcelas menores a las 250 has. (pero registraban los porcentajes más elevados de propiedad). Los gallegos encarnaban la figura del pequeño agricultor, que combinaba su explotación cerealera con animales domésticos y una huerta, donde solían cultivarse las legumbres y frutas para consumo de la familia y venta en los pueblos vecinos. Los vascos fueron los más favorecidos del sistema, en más del $51 \%$ de los casos trabajaban en parcelas entre 500 y 1.000 has. Además a diferencia de los otros grupos regionales un 2,5\% se encontraba en la categoría de 
grandes productores, por encima de las 2.000 has. y en su mayoría arrendando la tierra. Estos productores vascos desarrollaron explotaciones de mediana y grande dimensión, con un grado de organización y complejidad mayor. Sus estrategias productivas y de inversión combinaban agricultura y ganadería, compra de maquinarias, como medio de ahorrar costes salariales, y arriendo con propiedad como vía principal para ampliar y reproducir sus explotaciones.

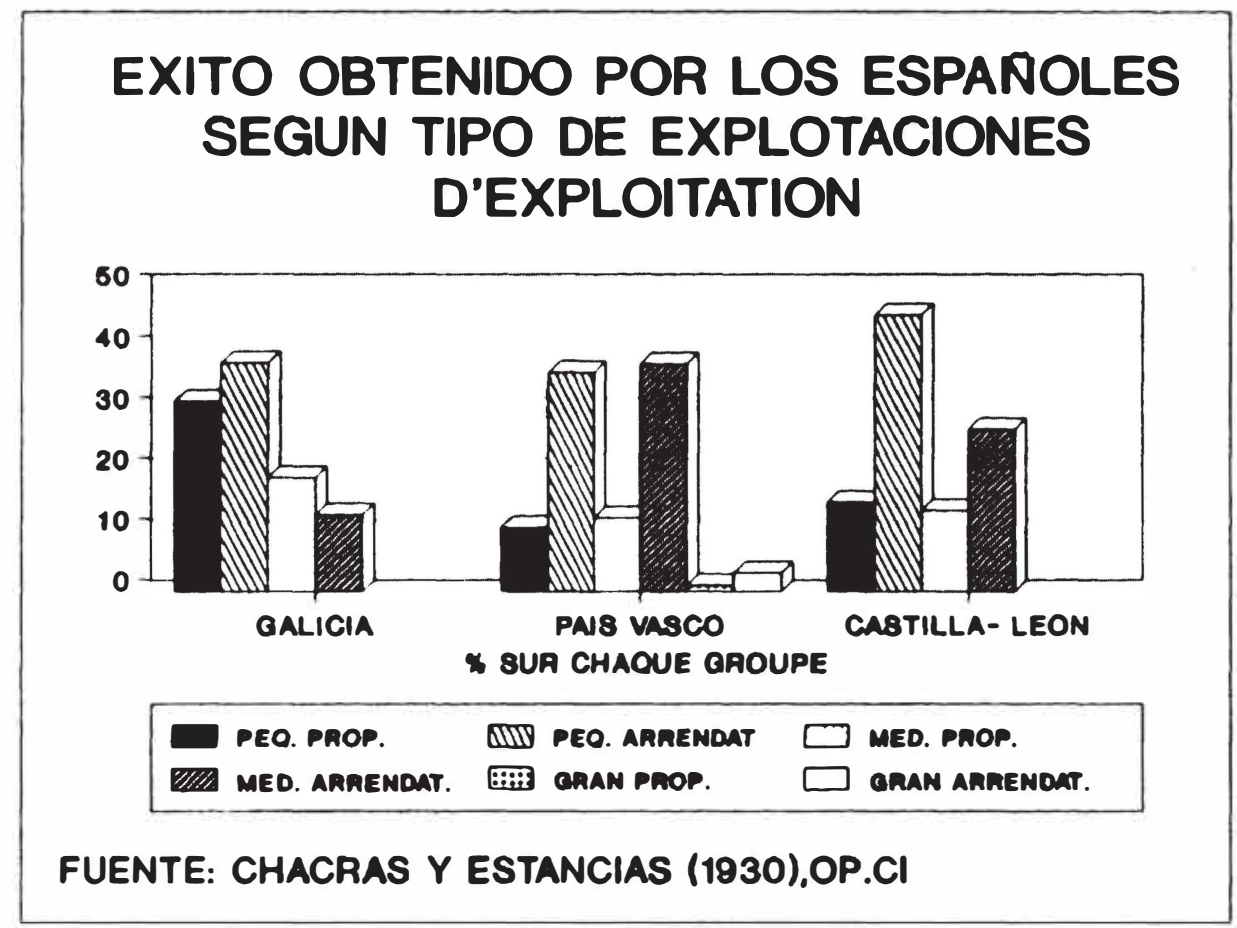

\section{GRÁFICO 2}

Los leoneses, se encontraban en una situación intermedia, distribuidos en forma pareja entre los pequeños y medianos productores. Una parte mayoritaria se dedicaba a la producción cerealera extensiva (combinación de alfalfa y trigo), actividad para la que tenían una mayor experiencia en razón de su tradición en la producción triguera en la meseta leonesa. Una parte más minoritaria de estos, había conseguido desarrollar grandes explotaciones con estrategias semejantes a la de los vascos. $\mathrm{Si}$ bien podríamos llegar a considerar un menor éxito relativo de los leoneses teniendo en cuenta el tipo de explotaciones que desarrollaron, tal conclusión es necesario relativizarla, puesto que era muy habitual en este grupo, la combinación del comercio y acopio de cereales, con las actividades agropecuarias. En cam- 
bio esta combinación productiva era menos frecuente en el caso de los vascos, que solian reinvertir su capital principalmente en las actividades agrarias (5).

ACCESO A LA PROPIEDAD EN TRES ARROYOS Y NECOCHEA (1929-1930)

\begin{tabular}{lcc}
\hline Nacionalidad & Propietarios & Arrendantarios \\
\hline Argentinos & 28,3 & 71,6 \\
Daneses & 17,4 & 87,6 \\
Españoles & 27,7 & 72,3 \\
Franceses & 36,3 & 63,7 \\
Italianos & 24,0 & 76,0 \\
\hline
\end{tabular}

Fuente: Base de datos sobre chacras y estancias.

En cuanto a la distribución entre propietarios y arrendatarios, los gallegos, presentaban el mayor peso relativo de propietarios con alrededor del 40 \% (tratándose en su mayoría de propietarios de pequeñas chacras de menos de 250 has.); los leoneses registraron en términos absolutos un mayor acceso a la propiedad de la tierra (6). En líneas generales, los españoles aparecen como uno de las comunidades con mejores posibilidades para organizar una explotación agraria, presentando niveles de acceso a la propiedad de la tierra semejantes a los nativos. Ademas la proporción sería incluso mayor, puesto que una buena parte de los nativos a cargo de explotaciones eran hijos de españoles (7).

En definitiva, las diferentes formas de acceso a la producción que hemos podido reconstruir nos estarían mostrando que no

(5) Hemos reconstruido la historia de más de setenta casos de productores agrícolas en el sur bonaerense y aparece muy claramente esta opción agrocomercio en los leoneses, frente a una estrategia más centrada en las diferentes actividades agropecuarias en el caso de los vascos.

(6) En otros trabajos hemos desarrollado el tema del acceso a la propiedad, sólo queremos remarcar dos cuestiones: un gran porcentaje de estos productores españoles compraron tierras durante la década del '20, favorecidos por la expansión de la producción cerealera, que posibilitó una mayor acumulación y por la política crediticia de los gobiernos radicales, que facilitó la compra de pequeñas parcelas.

(7) Este caso es particularmente llamativo para los vascos, debido a que son mas fáciles de detectar por su apellido y buena parte de los propietarios argentinos eran descendientes de inmigrantes de este origen, cuyas familias habian reemigrado de los partidos situados al norte de la provincia de Buenos Aires. 
fueron sólo los condicionantes "estructurales del sistema" los que orientaron el desarrollo de ciertas prácticas productivas, sino también un conjunto de acciones y de estrategias individuales que llevaron a estos hombres a organizar cada explotación con criterios y "racionalidades» diferentes y que podían vincularse con su propia experiencia anterior como campesino. La utopía de la tierra alcanzaba diferentes significaciones, según las estrategias personales, experiencias o tradiciones. La opción entre la compra de una pequeña parcela o el arriendo de una explotación mayor, no indicaba que el primer caso fuera más exitoso que el segundo. Para algunos, era preferible arriesgarlo todo en una gran explotación arrendada y no "conformarse" con una pequeña chacra de 40 has. Para otros en cambio, era preferible la mayor seguridad de al menos poseer un pedazo de tierra. Pero este hecho no puede llevarnos a afirmar la simpleza tantas veces. sostenida de que la propiedad de la tierra fue el elemento que marcó el éxito o el fracaso de los inmigrantes. Dicho más claramente, la posesión del factor tierra no fue para los inmigrantes el único indicador de riqueza o de acumulación, su adquisición fue una opción más, dentro de una gama de posibilidades ofrecidas.

Además, luego de reflexionar sobre la realidad agraria española pareciera que existiera una cierta relación entre las estrategias seguidas por estos productores en la Pampa y las tradiciones agrarias de sus sociedades de origen. Las semejanzas al interior de cada grupo, son realmente sorprendentes; si tomamos los datos generales de la estructura de propiedad en Galicia, León y el País Vasco, aparece una fuerte analogía con las estrategias seguidas en la Pampa: en Galicia predominaban los pequeños propietarios, en el País Vasco-Navarra el régimen de colonato, con una bajísima presencia de propietarios de las tierras; y en León si bien existía un numero importante de propietarios rurales, las explotaciones se repartían en un gran número de colonos arrendatarios. Si volvemos sobre el gráfico del tipo de explotaciones desarrolladas, aparece con claridad la predilección de parte de los gallegos por la compra de pequeñas parcelas; de los vascos por el arriendo en gran escala y de los leoneses por la combinación de arriendo y propiedad en explotaciones de mediana dimensión.

En suma, las posibilidades económicas presentadas a una parte de los inmigrantes españoles que lograron insertarse en el medio rural son harto evidentes, pero una pregunta queda aún 
sin respuesta ¿Fueron sólo las condiciones de la sociedad receptora las que posibilitaron este relativo éxito económico? ¿De qué sectores sociales provenían estos agricultores, que en pocos años lograron amasar una pequeña fortuna?

\section{Castilla-LeÓN: La EMigración a Ultramar en las tiERRAS DEL PAN Y EL VINO}

La estructura agraria tradicional de León y Castilla presentaba hacia fines del siglo XVIII un carácter latifundiario, con tierras en manos de grandes propietarios y la Iglesia y trabajada por un número elevado de arrendatarios (consignados en alrededor de 120.000) (8). Las desamortizaciones del siglo XIX conmocionaron apenas esta estructura productiva, que mantuvo un régimen de explotaciones fundado en la gran dimensión. Las tierras fueron compradas en su mayor parte por grandes empresarios agrícolas, beneficiarios directos del mencionado proceso de desamortización. Los historiadores españoles coinciden en afirmar que las desamortizaciones no significaron un incremento en el número de propietarios, pero como consecuencia de la expansión demográfica, se incrementó la capa de pequeños arrendatarios agrícolas, quienes solian combinar el arriendo con el trabajo asalariado.

A diferencia de Galicia o Asturias, los efectos de la crisis en Castilla no se hicieron notar hasta entrados los años 1880 , en que como consecuencia, de los altos costos de producción y de las malas cosechas de 1882-1883, comenzaron a entrar trigos importados, según el tradicional mecanismo para cubrir la demanda. Pero contrariamente a otros años, el ingreso de trigos foráneos fue increscendo. La explicación se encontraba en el cambio de la situación internacional: una fuerte depresión de precios externa e interna se había iniciado, al punto que hacia 1894, los trigos españoles desaparecieron prácticamente del mercado internacional y en los mercados regionales fueron poco a poco reemplazados (9). Esta fuerte depresión de los precios se producía en el momento en que León alcanzaba —entre 1886-1890 se produjeron

(8) R. R. HeRnÁNDEz, "Los arrendamientos castellanos antés y después de la crisis de fines del siglo XIX" en: Garrabou-Sanz, (comp.). Historia agraria de la España contemporánea, vol. I, Barcelona, Grijalbo, 1985.

(9) Para un análisis exhaustivo de esta cuestión ver (1988) R. Garrabou, editores La crisis Agraria de fines del siglo XIX, Barcelona, Crítica. 
records de cosechas- los puntos más elevados de producción luego del proceso desamortizador (10).

El cambio de coyuntura provocó desde mediados de 1880 , el paulatino abandono de las tierras ocupadas por el cereal y su reemplazo por otros cultivos - como legumbres, tubérculos, viñedos y ganado. Asimismo, los grandes productores frente a la dificultad de competir optaron más por el abandono de la producción cerealera que por la innovación tecnológica- decisión que hubiera podido redituar en el mediano plazo en una mayor productividad. Esta situación provocó el estancamiento de la producción de trigo, la disminución del nivel de actividad y el consecuente incremento del desempleo. En cambio, los pequeños agricultores prefirieron recurrir al mecanismo de la extensividad para cubrir los déficit de rendimientos (11). La mano de obra liberada, pequeños agricultores y jornaleros, encontró en la emigración temporal o definitiva hacia las grandes ciudades españolas o América, la mejor opción para modificar su situación.

Las características del proceso migratorio castellano-leonés se conocen con menor detalle que en otras regiones - como Galicia, Asturias o Canarias-, que por tener una mayor tradición emigratoria fueron objeto de mayor preocupación historiográfica. El momento en el que Castilla-León se incorporó a los flujos migratorios es considerado como parte de un ciclo nuevo y diferente del que habían protagonizado gallegos, asturianos, vascos o canarios. La tardía incorporación de esta zona, se relaciona con los efectos del modelo de crecimiento que inauguró la revolución liberal pues, a pesar de que el labrador no podía acceder fácilmente a las tierras que se liberaban de la desamortización, la posibilidad de transformarse en colono era menos riesgosa y más atractiva que el viaje a América. Pero con la crisis finisecular la coyuntura varió, la renta de la tierra se incrementó y el cereal pasó a no costar nada, por lo cual una de las alternativas mejores para la economía campesina fue el éxodo.

Este flujo de población se trasladaba a América en la mayor parte de los casos a través de los puertos de Galicia y Asturias -hecho que se explica por la vecindad geográfica y la tradición emigratoria de esas regiones- pero incluso se canalizaba por los puertos del sur donde, luego de una estadía previa en alguna

(10) Ver F. J. León Correa, Leín én el siglo XIX. Evolución, social, económica y cultural. León, Ediciones Leonesas, págs. 46 y 55.

(11) Ver C. HeRmida Revilla (1989), Economia agraria y agitaciones campesinas en Castilla la Vieja y Léón 1900-1936, Tesis de Doctorado de la Universidad Complutense de Madrid. 
gran ciudad como Madrid o Barcelona, emprendian el camino hacia América. Dentro de los destinos posibles en ultramar estos jornaleros y agricultores castellanos eligieron mayoritariamente las tierras del Río de la Plata, donde las necesidades de trabajadores agrícolas, la abundancia de tierras y el predominio del cultivo de cereales se adecuaba a su tradición campesina. A partir de fines de los ' 80 , los saldos migratorios se elevaron hasta el $79 \%$ del crecimiento vegetativo regional de 1888-1900 y entre 1911-1915, Castilla-León con 100.000 salidas, se convirtió en la segunda región emigratoria española (12).

Algunos poblados castellanos llegaron a quedar prácticamente despoblados; la situación era diferente en las capitales de provincia que atraían población. Pueblos enteros llegaron a trasladarse en pocos años a territorio americano, principalmente a la Argentina (13). Este tema fue preocupación constante de las prensas regionales y de algunos intelectuales que se inquietaban ante la vigorosa pérdida de mano de obra que afectaba los intereses de los grandes hacendados castellanos, quienes veían peligrosamente reducida su reserva de mano de obra. Esta información regional que hemos recogido (14) y que esconde en algunos casos los intereses que acabamos de mencionar, constituye una única vía, al menos para el caso castellano-leonés, para reconstruir el paisaje emigratorio. Las fuentes oficiales (estadísticas emigratorias y censos) recogen una información muy genérica y fragmentada, quedándonos la impresión de que si bien las autoridades intentaban desde un punto de vista formal ocultar la sangría poblacional, en la práctica se desinteresaban de los detalles de dicho fenómeno.

La emigración castellano-leonesa era descrita por los contemporáneos como un verdadero torrente poblacional que vaciaba en pocos años los poblados de la campaña de León y Castilla. Este fenómeno aparece muy bien planteado en una encuesta realizada por el más importante periódico de Salamanca El Ade-

(12) C. YáÑez Gallardo, demuestra que Castilla-León, junto a Galicia y Asturias participaron en la migración hacia Argentina, en una proporción mayor a su peso sobre la población de España, pág. 485. Ver también: A. de Francia CABallero "De León a Iberoamérica" en: Tierras Leonesas, León, no 73, 1985, págs. 325-342.

(13) Los relatos sobre pueblos castellanos que deciden emigrar en masa son comunes en esa época. Uno de los casos más nombrados fue el del pueblo de Boada, que pide a las autoridades argentinas el pago del pasaje para trasladarse a la Argentina.

(14) Hemos podido consultar las encuestas realizadas a principios de siglo por el periódico El Avante donde se entrevistaba a pobladores de la provincia de Salamanca y la Iglesia Católica y el estudio de J. Díaz Caneja, Apuntes sobre la emigración castellana, Palencia, 1908. Las conclusiones de los distintos estudios coinciden totalmente en cuanto al carácter y razones de la emigración castellana. 
lanto, que recorre los diferentes pueblos de los partidos de Béjar y Salamanca a lo largo del año 1913, en el momento más álgido de la crisis agraria. Esta información constituye una revelación impresionista de gran valor, para conocer las secuelas que la emigración tuvo sobre la vida de los pueblos. La emigración era definida por el periódico como «el problema más grave de nuestra tierra castellana que merecerá un estudio especial y detenido, con el objeto de poner de relieve sus causas y remedios principales" (15). La encuesta se ocupaba de tres cuestiones principales: la situación de los labriegos y jornaleros, la emigración y las noticias que había en el pueblo sobre la suerte de los emigrantes en Argentina.

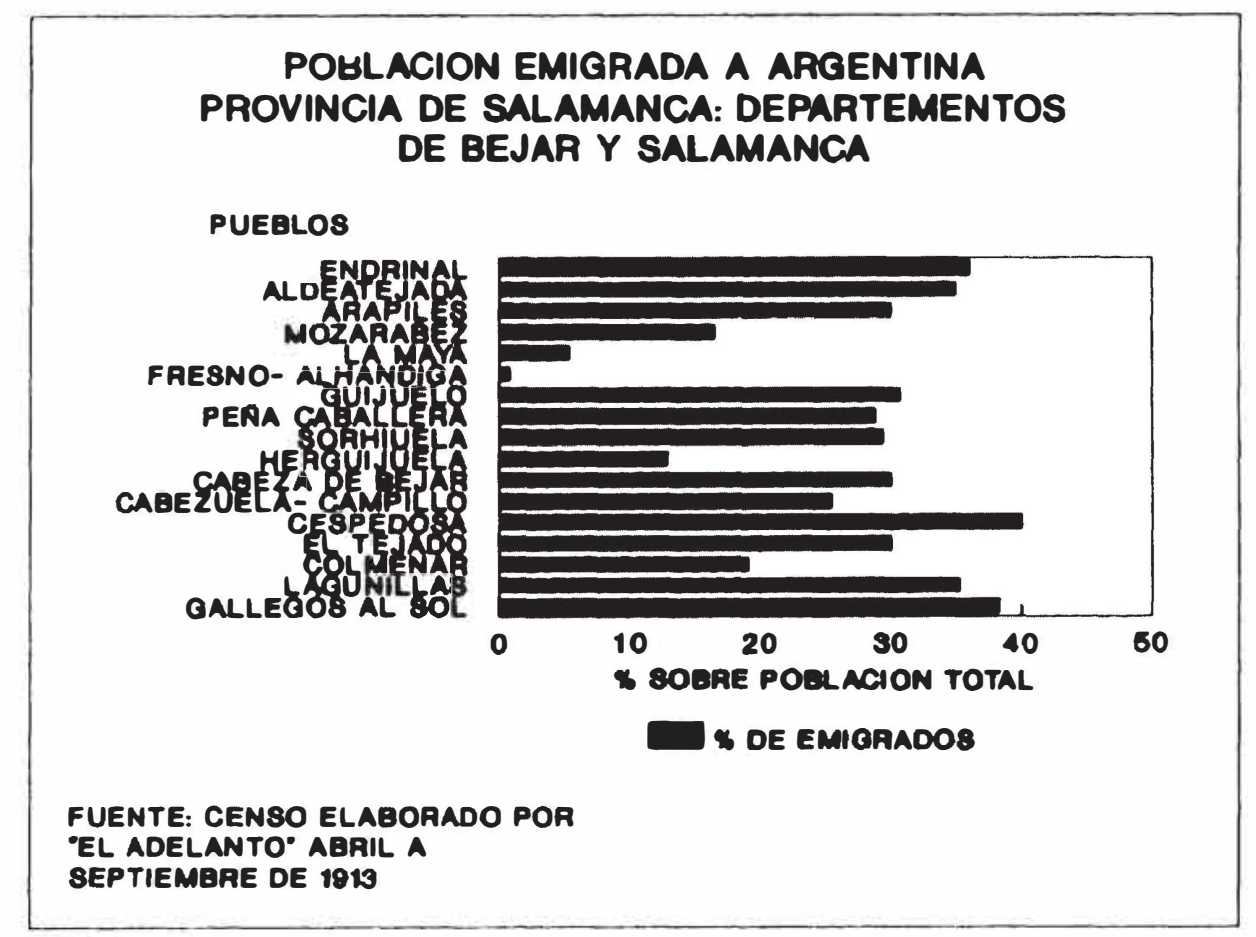

GráfICO 3

De la veintena de pueblos que recorren los periodistas por la provincia de Salamanca, algunos como Endrinai (partido de Salamanca) o Gallegos al Sol partido de Béjar), habían perdido en menos de una década alrededor del $40 \%$ de la población, lo que significaba en términos reales la desaparición casi completa de la fuerza de trabajo, solo quedaban los viejos y las mujeres jóvenes, muchas de las cuales también eligirían el camino de la emigración

(15) El Adelanto, Salamanca, 30 abril 1913. 
frente a las perspectivas del trabajo femenino en Argentina o del casamiento con algún paisano que allí residiera. En el pueblo de Mozárabez, una pequeña dehesa de 50 vecinos, los pobladores se quejaban por que no sólo habían partido los brazos jóvenes, sino hasta los dos sacerdotes y el maestro, habiendo quedado reducido el pueblo a escasas familias que no podían enviar sus hijos a la escuela ni satisfacer las «necesidades espirituales de los pobladores (16). En otros casos, la queja provenía de los propietarios y labradores que tenían que recurrir a pueblos cercanos donde la oleada migratoria no era tan fuerte, para poder conseguir allí, los brazos que recogieran a tiempo el cereal y que hicieran frente a los trabajos del campo durante el resto del año.

Los pobladores castellanos junto a los dramáticos comentarios sobre los efectos de la crisis agrícola, destacaban como un elemento acelerador de la emigración, el rol jugado por las noticias provenientes de las familias residentes en Argentina. Los comentarios frecuentes entre los pobladores y no exentos de un optimismo exagerado eran de este tenor: "Les va muy bien alli, una prueba de ello es el hecho que con frecuencia van y vienen, como si estuvieran a veinte metros de distancia y muchas veces traen dinero, que tras mucho trabajo han logrado economizar en aquellas tierras» (17). «De los pobladores de Gallegos del Sol, que emigraron a América -decía uno de los vecinos-, han hecho dinero muchos de ellos, como lo prueba los ahorros alcanzados por algunos que economizaron más de 1.000 pesetas en menos de un año", dinero que les alcanzaba para pagar varios pasajes a aquellos miembros de la familia que quisieran partir; un pasaje costaba, según la publicidad de los periódicos de la época, entre 180 y 200 pesetas.

Estos comentarios cargados de optimismo se reflejaban en las respuestas respecto del «éxito obtenido» por las familias instaladas en Argentina: en siete casos comentaban que les iba muy bien, hecho que coincidía con los pueblos de mayor emigración; en tres oportunidades respondían que les iba bien y sólo en cuatro pueblos, las noticias eran regulares o malas porque las expectativas de trabajo y de ascenso social no coincidian con la realidad. Cabe mencionar que los pueblos que registraban menor salida de familias eran aquellos que poseían una mayor diversificación productiva, el caso más evidente fue el de Fresno-Alhándiga donde sólo una familia vivía en Buenos Aires; la razón: que la

(16) El Adelanto, Salamanca, septiembre 1913.

(17) El Adelanto, Salamanca, 14 de mayo 1913. 
agricultura bajo riego permitía una producción más diversificada y una mayor productividad. En estos casos la utopía emigratoria y el efecto contagio se neutralizaban frente a las posibilidades ofrecidas en su tierra.

C. Díaz Caneja, profundizando en torno de las causas de la emigración, realizó en 1906 una encuesta sobre 250 ayuntamientos castellanos ofreciéndonos un diagnóstico preciso en torno de los factores de expulsión. El autor realiza una serie de preguntas a los propietarios, arrendatarios y jornaleros, en relación al precio de la tierra, los salarios, el costo de la vida y las causas por las cuales los labradores dejaban las tierras y emigraban. Veamos las principales conclusiones que se desprenden de su extenso trabajo: La emigración no fue una respuesta a problemas inmediatos de supervivencia, sino una opción frente a la caída de la rentabilidad, como lo indicaba que en mas del $80 \%$ de los casos, los labradores respondieron que con lo producido en sus explotaciones alcanzaban a cubrir los gastos de supervivencia familiar. La caída del nivel de actividad agraria en el que se conjugaban - según la especialización productiva-, la baja rentabilidad del trigo o los efectos de la filoxera sobre las vides y el incremento de la renta de la tierra, fueron los factores principales que llevaron a las familias campesinas a considerar la opción de la emigración a América. El autor destacaba también los efectos negativos de las prácticas agrícolas tradicionales que habían infertilizado las tierras, agudizando los efectos de la caída del nivel de rentabilidad; combinación explosiva que llevaba a su vez a un círculo vicioso de empobrecimiento que impedía al pequeño propietario y al labrador elevar el salario al jornalero, pues en caso de hacerlo no alcanzaba a superar sus costos de producción (18).

El salario de los jornaleros y según los datos que nos brinda la encuesta no superaban en los períodos de mayor demanda las dos pesetas, mientras que un jornalero en Buenos Aires y tomando los datos de un periódico salmantino caracterizado por un discurso fuertemente anti-emigratorio, era de 12 pesetas diarias, lo que equivalía a un salario diez veces superior al que se le ofrecía en el mercado de trabajo local. Por tanto, es muy comprensible a la luz de estas diferencias salariales, que jornaleros y labradores emigraran atraídos por las posibilidades de ahorro

(18) Ver Díaz Canfja [15], págs. 103-104. 
que se les of recía en el Río de la Plata (19). Sin embargo, ante la alternativa del empobrecimiento no todos respondieron de manera uniforme, la crisis finisecular fue una suerte de telón de fondo que creo las condiciones objetivas de emigración, pero la circulación de información entre los vecinos y familias y las redes informales que se fueron creando a lo largo de décadas, generaron una suerte de efecto en cadena, en donde el "contagio" emigratorio terminaba acelerando la partida de sus habitantes. Este "torrente» emigratorio no presentó en las diferentes zonas una regularidad aritmética, ciertos lugares y pueblos donde se asentó la tradición emigratoria por la partida de "adelantados", llegaron a quedar prácticamente despoblados, mientras que otros villorrios cercanos que padecían situaciones económicas semejantes, apenas si fueron tocados por la marea emigratoria.

\section{ORIGEN SOCIAL Y FAMILIAR DE LA EMIGRACIÓN}

Ahora bien, ¿cuál era el origen social y familiar de estos campesinos que abruptamente fueron abandonando los pueblos leoneses de la Vieja Castilla?

Recrearemos esta problemática a través de las Actas de licencias para emigrar, se trata de una documentación que comenzó a ser exigida a los emigrantes menores y a las mujeres a partir de 1908 (20); dichas actas están compuestas por los certificados de antecedentes penales y de salud -que por su contenido pareciera que se elaboraban para cumplimentar la formalidad-

(19) La voz de la Frontera, 1890. Ciudad Rodrigo, Prov. de Salamanca, E. SORI, "Las causas económicas de la emigración italiana, entre los siglos XIX y XX", en: F. Devoto, La inmigración italiana a la Argentina. Buenos Aires, Biblos, 1984, analiza una situación semejante para los jornaleros italianos que se tentaban con la opción emigratoria por el diferencial de salario que podian ganar en Estados Unidos (6, 7, o 15 liras diarias), o la ganancia mensual que podían obtener en Argentina, semejante al ingreso anual de un jornalero en Italia, op. cit., pág. 36. R. CORTÉs CONDE, El progreso argentino. Buenos Aires, 1978. Sudamericana; considera el diferencial salarial, como el elemento explicativo principal a la transferencia de mano de obra de las regiones europeas a los Países Nuevos.

(20) Una parte de la información la localizamos en el Archivo Provincial de León, allí recogimos la información correspondiente a los pueblos de la zona de Murias de Paredes para 1908-1922. En el ayuntamiento de Fresnedo (El Bierzo), hemos localizado la otra parte de la información. En total hemos logrado reunir 300 actas de emigración para estas dos regiones, hecho que nos permitirá hacer una comparación entre ambas. Para complementar nuestro estudio hemos consultado los siguientes periódicos: León, publicación de la Asociación Centro Región Leonesa, (1919-1960); Vida Leonesa, semanario leones. (1919-1925); El Alcázar, León (1880-1890); Mensajero leonés (1903-1905) El Adelanto, Salamanca, 19001920; El Avante, Ciudad Rodrigo, (1900-1920). 
y el acta de autorización propiamente dicha, que contenía información sobre el autorizante y el emigrante: sexo, edad, profesión, lugar de residencia, fecha de salida y país de destino. En el caso de las actas que localizamos en Fresnedo (El Bierzo) contenían también información sobre las causas de emigración este precioso dato nos permitió determinar la importancia creciente del mecanismo de llamada familiar. Lamentablemente nuestro universo no es muy grande, pues sólo hemos localizado los expedientes para dos ayuntamientos en León, el de Vegarienza perteneciente al partido de Murias, en la región montañesa y el de Fresnedo perteneciente al partido de Ponferrada, en El Bierzo, sumados constituyen un universo de 297 casos que cubren el período de 1908 a 1928.

Ademas del número de casos circunscrito, la limitación principal que presentaría nuestra fuente es la de no registrar el flujo ilegal que salía por los puertos gallegos, asturianos o portugueses. Esta emigración ilegal estaba compuesta en gran parte por los desertores al servicio militar que alcanzaron durante la Guerra de Marruecos porcentuales elevados. Para todo aquel que no podía pagarse un reemplazo, la alternativa de América le resultaba más barata y atractiva. Pero si bien este flujo ilegal debió ser muy fuerte en algunas coyunturas históricas, también se considera que a partir de la liberalización que significó la ley de 1907, comenzaron a reducirse el número de salidas ilegales al haber desaparecido el mecanismo formal prohibitorio.

La Ley de Emigración de 1907 consta de 185 artículos y en ellos se regula todo lo referente al Régimen de la Emigración, constituye según la opinión de los contemporáneos, una continuidad en la concepción y evolución legislativa que en materia de emigración se instauró desde principios de este siglo. Dicha ley significó un paso adelante en la tendencia a la eliminación de trabas a la emigración, disminuyendo los trámites burocráticos que se exigían al futuro emigrante. Esta ley venía a responder ${ }_{\perp}$ a las peticiones de algunos sectores que exigían desde los últimos diez años la liberalización del flujo emigratorio y dejaba en apariencia escaso margen a la clandestinidad. Pero una vez que los primeros temores fueron superados entre los interesados en el negocio del tráfico ilegal, al comprobar que la Administración no estaba dispuesta -o no podía - aplicar la nueva legislación, los mecanismos ilegales se restituyeron rápidamente para encauzar parte del flujo migratorio. Aunque pareciera, como señalábamos, este último descendió marcadamente respecto de otros 
periodos (21). Una prueba de ello es que los autores que compararon las estadísticas argentinas y españolas han mostrado como este flujo ilegal no debió ser tan significativo, pues las estadísticas de ambos países no presentan grandes discordancias.

De todas maneras y volviendo a la representatividad de las Actas de emigración consideramos que más allá de que oculte parte del flujo ilegal -que de todas maneras no podemos consignarlo ni siquiera estimativamente-, esta fuente nos presenta el atractivo de permitirnos reconstruir con cierto detenimiento los origenes familiares del emigrante, sus edades y las estrategias de emigración del grupo familiar. Si bien en relación a los cuantum poblacionales que emigraron de cada localidad no puede generalizarse - ya hemos visto la disparidad existente en los porcentuales de salidas en los distintos pueblos- podemos considerar algunos referentes para encuadrar la representatividad de casos que poseemos. Si realizamos un pequeño juego aritmético, podremos ver que para el universo poblacional de Vegarienza y Fresnedo, el numero de emigrantes contabilizados en nuestra fuente constituye un porcentaje significativo sobre la población total que efectivamente debió emigrar. Tenemos respectivamente 139 y 158 actas de emigración (algunas de las cuales fueron realizadas para más de un emigrante, por ej. varios hermanos o hermanas que emigraban juntos), elaboradas entre 1908 y 1922 las de Vegarienza y entre 1912 y 1928 las de Fresnedo. El total de población que establece el censo de 1920 (que incluye las pequeñas comarcas de donde salen los emigrantes) es de: 1.366 habitantes para Vegarienza y de 2.285 para Fresnedo; diez años después la población había disminuido en términos absolutos a 1.295 y 2,272 respectivamente. Respecto del censo de 1920 las actas representaban una perdida poblacional de alrededor del $10 \%$ y el $7 \%$ sobre la población total, porcentaje por cierto nada desdeñable, si tenemos en cuenta que se trata de población en edades económicamente activas y de que no todos los potenciales emigrantes eligieron América.

(21) Aún después de la Ley de 1907 abandonar el país, significaba para el futuro emigrante un complejo entramado de trámites que debía cumplir para la obtención del pasaporte. La mayor o menor facilidad de hacerse con dicho documento dependía no sólo de la legislación vigente, sino también, de la escrupulosidad o tolerancia del funcionario y de la posibilidad de acceso a los mecanismos no legales de expedición de pasaportes. Si estos medios no funcionaban, no había más alternativa que intentar salir clandestinamente. 


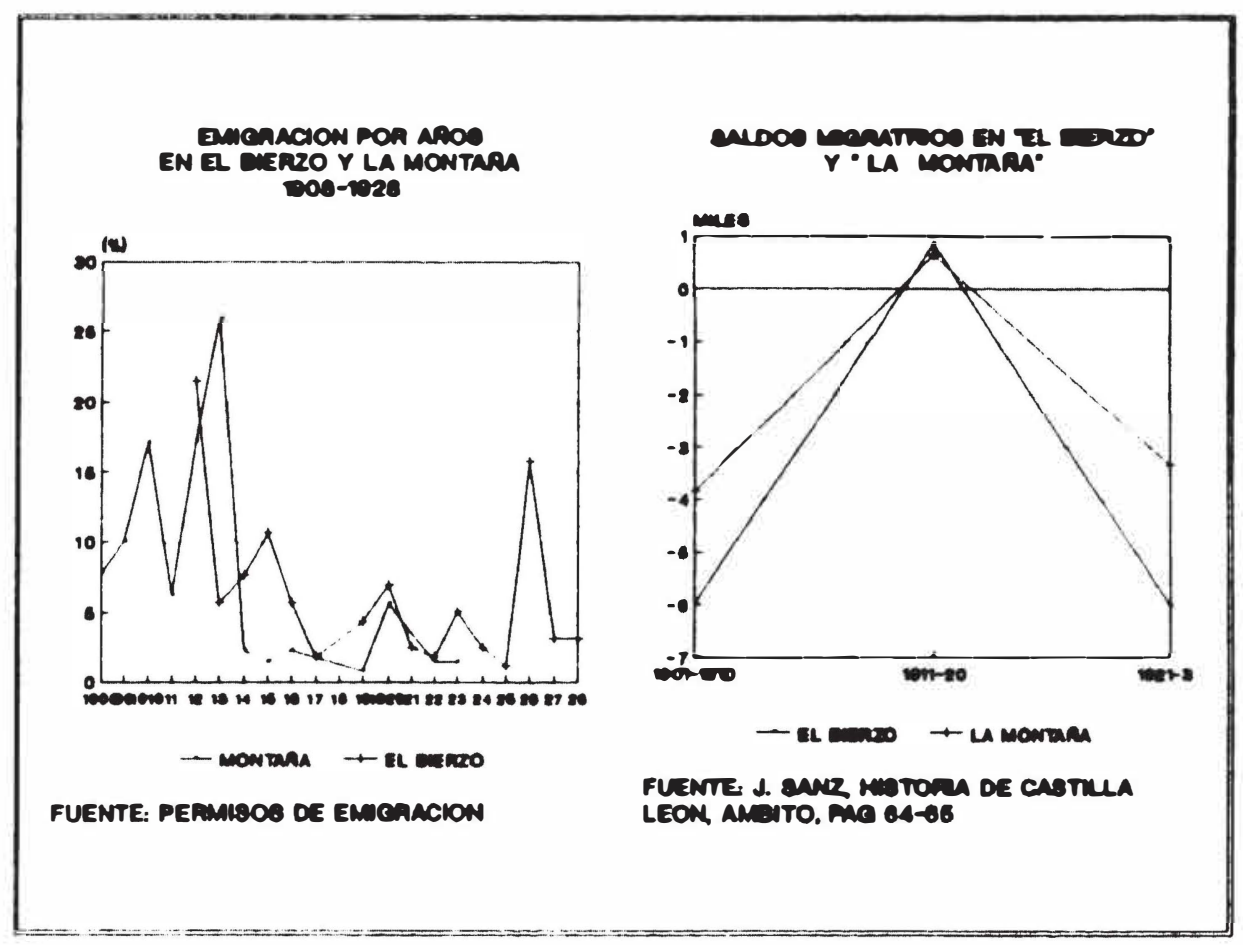

GRÁFICO 4

Si volcamos sobre una gráfica la cantidad de salidas anuales que se registraron para cada zona y la superponemos a los saldos migratorios, comprobamos que ambas curvas coinciden temporalmente; los porcentuales mayores de salidas se produjeron hasta 1913. Los años de la I Guerra Mundial debieron afectar los traslados a ultramar, hecho que se reflejaba en la disminución del número de casos hasta los años 1919-1920, fecha en que recomenzaron los pedidos de autorización, coincidiendo con un nuevo período de saldos emigratorios negativos en el conjunto de El Bierzo y la Montaña. Otro dato coincidente, que también se refleja a través de las Actas, es el incremento de salidas a partir de 1925 y 1926 en la zona del Bierzo y la disminución de los saldos en la zona montañesa debido en parte, como señalamos mas arriba, a las actividades mineras que incrementaron el nivel del empleo.

Nuestra fuente confirma la unanimidad respecto del destino elegido: más del $95 \%$ de los casos en Vegarienza y del $84 \%$ en Fresnedo fueron solicitudes para emigrar a Argentina; el porcentaje restante, para Cuba, México, Estados Unidos y Brasil. Sólo un $2 \%$ de os emigrantes eligieron como destino este último país 
y se trataba coincidiendo con las opiniones historiográficas, en todos los casos de jornaleros (22).

Los datos sobre edad y sexo de los emigrantes muestran la salida de población masculina y femenina en los inicios de su vida activa. Según los permisos de la zona de la Montaña salieron más hombres que mujeres (100 hombres y 39 mujeres), y desde el Bierzo la proporción fue a la inversa 75 hombres y 83 mujeres. Esta asimetría entre las dos regiones se mantenía en torno a la edad de los hombres y mujeres; en la montaña el promedio de edad era más bajo para los hombres que entre las mujeres. Más del $46 \%$ de los casos de los emigrantes eran varones entre 16 y 20 años, el porcentaje caía marcadamente para el grupo de 20 a 25 años (14\%) y era prácticamente insignificante para el resto de los grupos. En El Bierzo, en cambio, aparecía una distribución mayor entre los grupos de edad de más de 20 años; en un porcentaje importante de casos se consignaba solamente «mayores de edad" (38,6\%) tratándose de autorizaciones de varones de más de 23 años. En estos casos se certificaba el cumplimiento del servicio militar y la inexistencia de antecedentes penales, requisito exigido por las autoridades españolas y argentinas.

Esta diferencia entre los grupos de edades de una y otra zonas, puede deberse al hecho de que ambas regiones - como decíamos más arriba- formaron parte de ciclos emigratorios diferentes. La salida masiva de jóvenes de menos de 20 años, si bien puede estar indicando la limitación del servicio militar, también puede estar mostrándonos la expulsión del excedente de población frente a las limitaciones de la estructura productiva. En cambio en El Bierzo, es evidente que buena parte de los emigrantes eran jefes de familia que decidieron esta opción frente a la falta de perspectivas económicas, constituyendo una primera fase de emigración a la que luego seguirían los hijos varones y las mujeres de la familia.

En las mujeres de la Montaña, el promedio de edad se elevaba respecto de los hombres, un $24 \%$ eran mujeres solteras entre 24

(22) Para un análisis sobre la relación entre país de destino, pasajes subdiados y orígenes de los emigrantes, ver por ejemplo los trabajos de: Elda González, "Andaluces en São Paulo. Un estudio sobre emigración contemporánea" In: Historia general de la emigración a Iberoamérica; Madrid, H. 16, 1992, págs. 177-200. Café e inmigración: los españoles en Sao Paulo 1880-1930, Madrid, CFDEAL, C. Naranjo Orovio (1986), "Canarios en Cuba en el siglo XX" en: VII Coloquio de Historia Canario-Americano, Gran Canaria 1986, págs. 515-536; B. SÁnCHEz. Alonso (1992), La inmigración española en Argentina en los siglos XIX y XX, Edic. Júcar y A. BERNAL, "La emigración de Andalucía", en: Españoles hacia América, Madrid, 1988, págs. 143-165. 
y 30 años, edad bastante elevada para la época. El casamiento en poblados vacíos de hombres, debió ser una de las razones principales de su partida. Lamentablemente la fuente no indica en todos los casos la razón del pedido de autorización, aunque en algunos menciona que había sido llamada "para casarse en America". También era común que emigraran varias hermanas, o primas con un "pre-contrato" aceptado por los padres para trabajar en casa de algún paisano en América. Este último caso era el que predominaba en El Bierzo, donde la emigración de mujeres muy jóvenes para realizar trabajos domésticos fue muy importante: el $12 \%$ de estas tenían entre 11 y 15 años y un $40 \%$ entre 16 y 20 (23).

En relación al momento de partida, las fechas en que fueron elaboradas las actas confirman que la época de mayores salidas de emigrantes se relacionaban con los ciclos del mercado de trabajo en ambos continentes. Sin excepción, las fechas de las actas (que se concentraban en los meses de septiembre a enero, coincidían con el fin del verano europeo y comienzos de primavera-verano en el continente sudamericano, momento por demás propicio, por la iniciación de las actividades de cosecha, para obtener un primer empleo. En el caso de la emigración femenina las salidas se distribuían durante todo el año, la demanda del trabajo doméstico no se vinculaba necesariamente a la del ciclo agrario.

\section{PROCEDENCIA FAMILIAR}

¿De qué familias provenían estos jóvenes emigrantes que estaban dispuestos a hacer la América, aún al precio de realizar durísimos trabajos en el Río de la Plata?

Cuando comenzamos a procesar la información nuestra sorpresa inicial fue muy grande ante el perfil de emigrante que comenzaba a delinearse ante nuestros ojos, poco tenia que ver con aquel estereotipo de inmigrante analfabeto y trabajador sin calificación, que la tradición intelectual y el sentido común habían construido en el Río de la Plata. Estos emigrantes castellanos

(23) En las entrevistas realizadas entre los leoneses de Tres Arroyos, esta modalidad de immigración de mujeres solas (generalmente hermanas o primas) para trabajar en las casas de paisanos y familiares acomodados, aparecía muy extendida. En los permisos como veremos, constituía uno de los principales mecantismos de llamada de las mujeres del Bierzo. 
provenían en su mayor parte de familias de labradores y pequeños propietarios (o eran ellos mismos labradores); la presencia de jornaleros o peones fue muy poco significativa (24). El hecho de que la experiencia emigratoria los haya obligado a realizar diferentes trabajos, que se adaptaban más a las necesidades del mercado de trabajo argentino que a su propia calificación de agricultores, no es óbice para generalizar en torno del tipo de inmigrante que arribó a las orillas del Plata. Veamos los datos con mayor precisión:

En la Montaña, alrededor del $50 \%$ de los familiares que autorizaban al emigrante declaraban ser labradores y un $21 \%$ propietarios agrícolas; en El Bierzo un $60 \%$ eran labradores y un $2 \%$ propietarios (25). Como se constata en el tráfico $n^{0} 5$, el esquema ocupacional se repite cuando analizamos las profesiones que declaraba el emigrante. En este último caso, la falta de información es muy fuerte debido a que en la mayor parte de las actas, salvo que se tratara de hombres adultos, no se consignaba el dato profesión; el $24 \%$ de los casos registrados eran gran parte de los jefes de familia a los que hacíamos referencia más arriba. La baja presencia de los jornaleros (5,1 \% en la Montaña y 2,5\% en El Bierzo) es atribuible a las menores posibilidades de emigrar que tenían estos trabajadores; para un jornalero el costo del pasaje era inaccesible (26), además, sus posibilidades de participar del flujo migratorio legal - hemos mencionado el conjunto de trabas burocráticas- debieron ser mucho menores que para los labradores y propietarios. Además, este número reducido de jornaleros se debía también, a las peculiaridades de la estructura agraria de Castilla-León, que a diferencia de otras zonas como

(24) Nuestra comprobación confirmaba una vez más la extendida hipótesis que considera que el tipo de emigrante que salía de las diferentes regiones europeas no provenía de los sectores más pauperizados de la sociedad. Al respecto ver por ejemplo el análisis de F. Devoto, Movimientos migratorios. Historiografia y problemas, Buenos Aires, CEAL, 1982.

(25) Cabe aclarar que esta presencia relativamente baja de propictarios se debía a que el Juez de Paz colocaba como profesión labradores y propietarios indistintamente, pues en algunos casos hemos podido corroborar que el emigrante o el familiar se declaraba en algunas actas labrador y en otras propictario. Además, este esquema ocupacional de los emigrantes no hace más que confirmar las características de la distribución de la tierra en León, donde predominaban en proporciones semejantes pequeños propietarios y arrendatarios de tierras. Ver LEÓN CORREA [11].

(26) Estimaciones realizadas, consideran por ejemplo que para un jornalero canario trasladarse a Cuba le implicaba un costo entre 80 y 150 jornales; para un asturiano o gallego ir al Río de la Plata entre 100 y 200 jornales. 
Andalucía, poseía una presencia menor de este tipo de trabajadores.

El grupo "quehaceres de su sexo" estaba constituido por las mujeres que autorizaban a sus hijos y esposos a emigrar y asimismo esta era la ocupación que declaraban en su mayoría, las hijas mujeres que emigraban. Pero cabe mencionar, que una buena parte de las mujeres que aparecen dando la autorización, se declaraban como labradoras, lo que nos está indicando que habían quedado como responsables de la economía familiar.

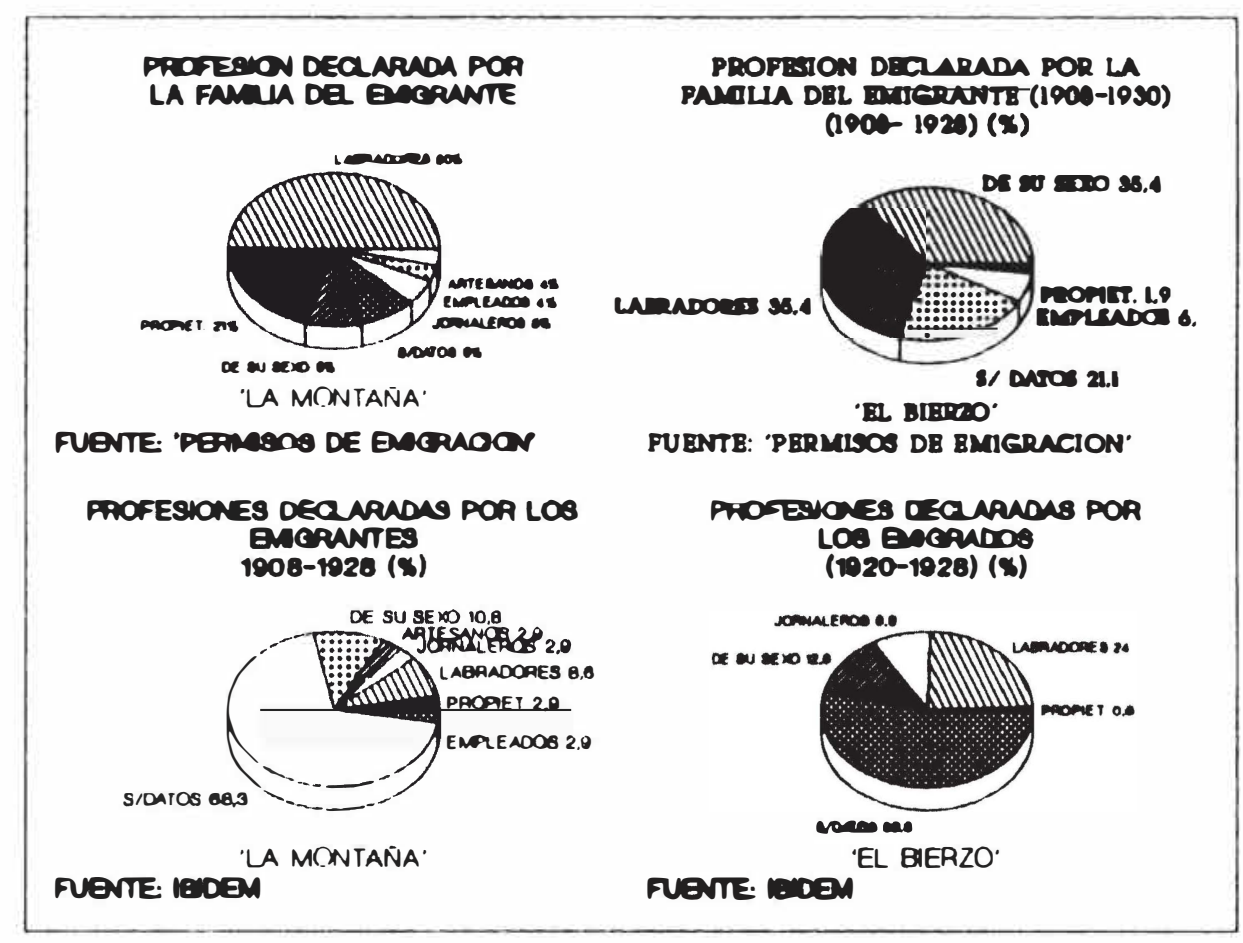

GrÁFICO 5

Los pequeños propietarios y labradores constituyeron la franja ocupacional más apta para iniciar una experiencia emigratoria. Las pequeñas propiedades no alcanzaban para "alimentar» y satisfacer las necesidades de todo el grupo familiar, pero sí constituían un respaldo económico para iniciar la experiencia migratoria. El capital que implicaba la pequeña propiedad, podía ayudar a financiar el viaje y los primeros tiempos de instalación, a la vez que asegurar la manutención de los que quedaban. Si no se poseía el capital líquido necesario, podía recurrirse a los mismos mecanismos financieros que otrora se utilizaban para los gastos de la explotación. Si bien en un par de meses de arduo trabajo, economías y buena suerte, podría juntarse el dinero del pasaje 
en Buenos Aires, no todos estaban en condiciones de poseer ese monto para afrontar el viaje. Un jornalero que apenas ganaba unos reales al dia, tenía escasas posibilidades de hacerse con el dinero. El periódico El Avante de Ciudad Rodrigo, denunciaba asiduamente la suerte corrida por algunos labradores que se habían dejado "seducir" por las facilidades para obtener dinero para el viaje, ofrecidas por los capitalistas locales, quienes actuaban en relación con los ganchos. Las elevadas tasas de interés arruinaban la economía de la familia que quedaba en España (27).

\section{ANTE TODO UN «COMPROMISO» DE FAMILIA: ESTRATEGIAS DE LA EMIGRACIÓN}

Una pregunta se encuentra en el trasfondo de esta cuestión y se enlaza con lo que venimos analizando. ¿Qué estrategias seguía el hombre que decidía emigrar, ésta era una decisión que tomaba en la soledad de sus pensamientos o se discutía en el seno de la familia? ¿Tal decisión afectaba sólo su destino individual - como se desprende de algunas opiniones historiográficas-o incluía al entorno familiar que rodeaba su vida cotidiana? Una primera respuesta nos surge espontáneamente: un individualismo tal, no era imaginable para la idiosincrasia de un campesino leonés o castellano, pues su vida personal estaba en función estrecha a la del grupo familiar. El acto de emigrar formaba parte de una decisión colectiva y la partida de uno de los miembros no implicaba en la mayor parte de los casos una ruptura, sino una continuidad de la relación (28), las responsabilidades del que se iba no finalizaban con la partida, sino incluso se incrementaban, pues no solo debía ayudar al sostenimiento y reproducción familiar en España, sino colaborar en la partida y asentamiento de los futuros miembros que quisieran hacerlo. Lo dicho no significa

(27) Ver especialmente El Avante 24 mayo 1913, 25 de julio 1914 y 10 de julio 1915, Díaz Cancja [14], opinaba de forma semejante al periódico de Ciudad Rodrigo; consideraba que uno de los mecanismos más comunes, al que recurrían los pequeños propietarios y labradores de Castilla, para obtener el dinero líquido para emigrar, era el de pedir dinero a los mismos capitalistas que solian linanciar las cosechas con anterioridad.

(28) Creemos, necesario aclarar que cuando nos referimos a la continuidad de la relación de la familia de un lado y otro del Atántico, no estamos presuponiendo un modelo ideal de familia de campesina en la que las "decisione's" se tomarán en un clima de armonía v consenso v exentas de conflictos. Para un análisis de las diferentes concepcione's de familia ver M. SI:CiAl. Ne. Sociologice de la famille, Paris, A. Colin, 1992. 
afirmar, que una vez instalado en la nueva realidad, el "olvido" de las responsabilidades asumidas no haya sido común entre los emigrantes -ingenuo claro; sería sostenerlo-, pero el costo de esta decisión también era claro; asumir el destino individual implicaba perder el referente protector de los lazos familiares y no todos estaban en condiciones o dispuestos a afrontar tal riesgo material y psicológico.

Pero comencemos por descubrir a través del acto formal y ritual de otorgar la autorización de emigrar, la forma en que se ejecutaba la decisión familiar. Eran los padres, mayoritariamente, quienes otorgaban las autorizaciones a sus hijos para dirigirse a América, constituyendo el punto de partida de la futura experiencia migratoria del grupo familiar. Años más tarde, si la experiencia del "pionero» era positiva se le agregaría una parte o la totalidad de la familia. El traspaso de la autoridad paterna a la materna -el porcentaje representado por las esposas y madres otorgando la solicitud (30\% en la Montaña), no es nada desdeñable-, fue el primer indicio con que nos encontramos de la emigración progresiva del grupo familiar. Esta estrategia permitía, como es obvio suponer, disminuir los riesgos de "quemar las naves" manteniendo las opciones de un lado y otro del Atlántico.

El mecanismo más extendido para llevar adelante la experiencia migratoria, fue sin lugar a dudas el de reunificación del grupo familiar. Es decir, que a la salida de uno de los hijos -generalmente el mayor, pero no en todos los caso- o del jefe de familia, se le sumaba en años siguientes los miembros restantes (hermanos, padre o madre). El primer miembro que era "elegido" para emigrar, jugaba el rol de "pionero" siendo el encargado de recabar información sobre las posibilidades de trabajo y de ahorro (29), este primer eslabón se transformaba en el puente de enlace para dinamizar la cadena cada vez que un miembro de la familia nuclear o extensa quería emigrar. Esta estrategia de reencuentro familiar podemos ilustrarla en el ejemplo siguiente:

(29) Este mecanismo aparece descrito en forma muy semejante en un estudio realizado para el caso de emigrantes mejicanos a Baja California R. Álvarez, (Familia. Migration and adaptation in Baja and Alta California, Berkeley, University of California Press (1986). 
a) TIRSO CORRAL MATA (Labrador en Finolledo, El Bierzo)-...-.-

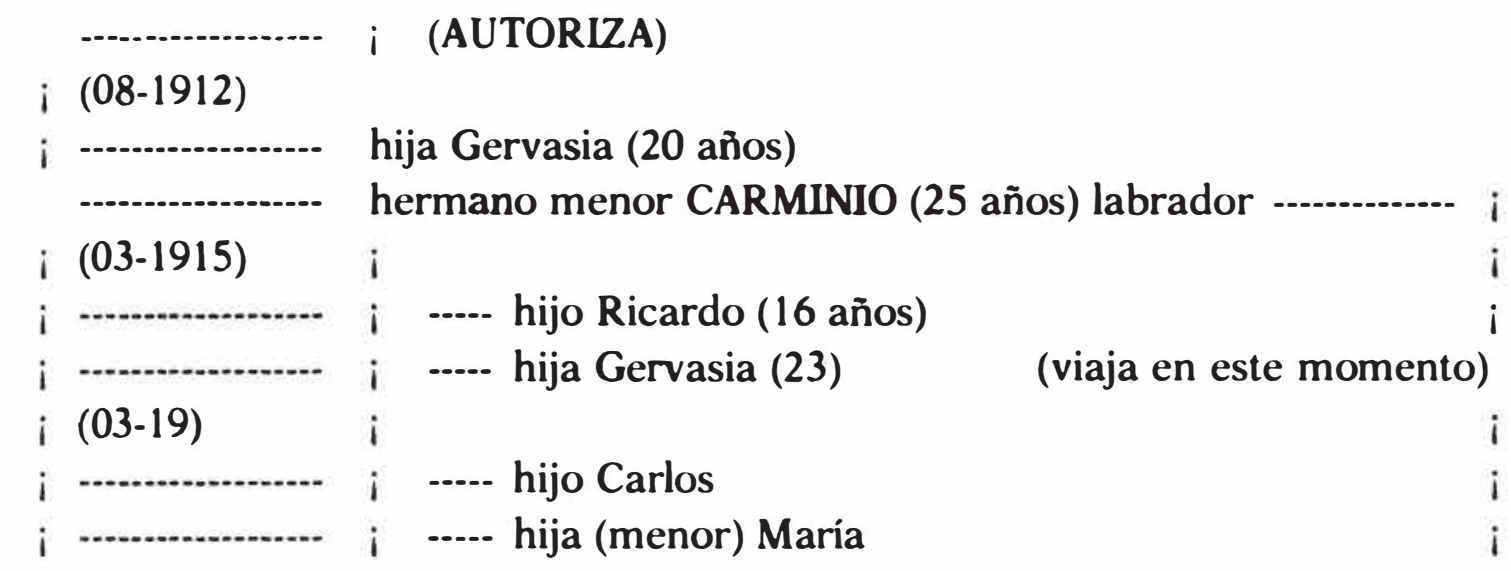

Todos por llamados de su Tío Carminio ya asentado y trabajando en Argentina

b) JUAN OVALLO MATA (primo del anterior) (Propietario en Finolledo)

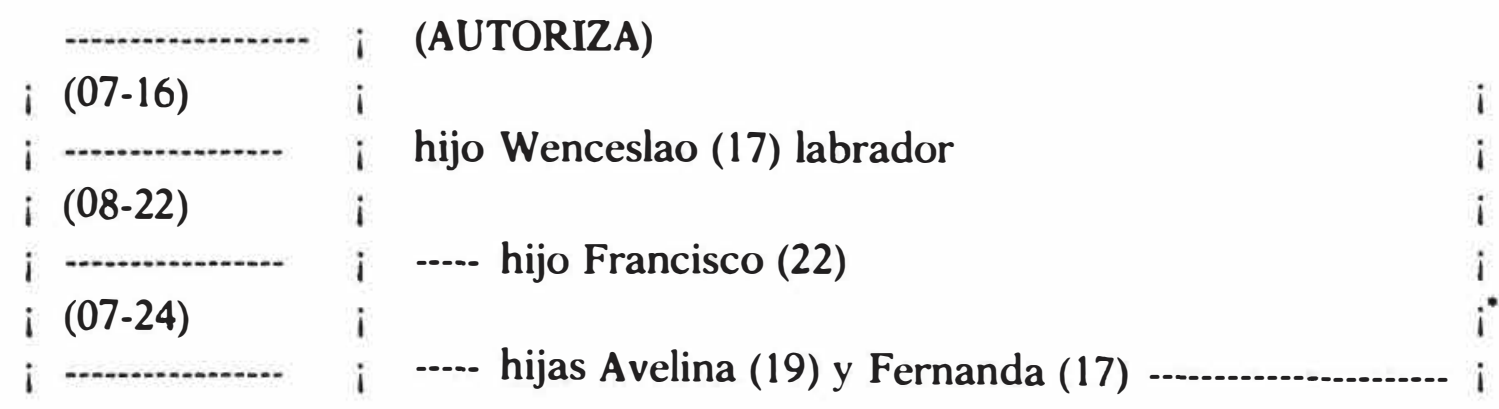

- también llamados por Carminio desde Argentina.

El hermano mayor y jefe de familia, Tirso, autorizó a su hermano menor Carminio para que emigre a Argentina en 1912. Desde su partida hasta que volvemos a tener noticias de él habian transcurrido entre tres y cuatro años, tiempo mínimo y necesario para ubicarse en el Río de la Plata. A partir de 1915 y durante mas de una década Carminio jugo un rol activísimo en el traslado de gran parte del grupo familiar a Argentina. A través de las Actas puede determinarse, también, cómo a medida que crecían sus sobrinos, es decir que se transformaban en mano de obra apta, su tío los "mandaba llamar» desde Argentina para ocuparlos. En el caso de los Corral Mata y Ovallo Mata, la familia quedó dividida de un lado y otro del Atlántico, pues no llegó a emigrar - hasta donde nos muestran los permisos- ni el padre ni la madre; es decir que Tirso y Juan, los jefes de familia, continuaron como responsables en España de la economía fami- 
liar. En otros casos era bastante común, que al cabo de unos cuantos años también se trasladase el jefe de familia, habiendo dejado en manos de algún hijo o sobrino los bienes que hubieran podido quedar en España, emigrando - como podemos deducir de las edades que aparecen en las Actas- más que por razones económicas para pasar los últimos años de su vida junto a la parte de su familia que había quedado del otro lado del Océano (30).

La importancia del mecanismo de llamada queda corroborado si nos adentramos en las causas de partida que declaraban los futuros migrantes. Esta preciosa información sólo la poseemos para el caso de El Bierzo, donde el Juez de Paz en cada acta establecía la razón por la que la persona se iba; en la Montaña lamentablemente esta pregunta era obviada. En el 62,6\% de los casos el candidato afirmaba que pedía autorización para buscar trabajo en las tierras del Plata, en un $24 \%$ no existía respuesta y el 13,5 \% declaraban que emigraban por llamado familiar. Si bien este porcentual a primera vista puede parecer poco significativo frente a los que decían emigrar para buscar trabajo individualmente, esta modalidad adquiere mayor significación si situamos los datos sobre la coordenada temporal. El mecanismo de llamada tuvo un peso mayor en la década de 1920 (con más de $30 \%$ de los casos) y luego que la primera generación de pioneros había alcanzado una cierta posición en Argentina, fue en este momento que el mecanismo de "cadena" comenzaba a funcionar más aceitadamente.

Los datos que poseemos para Argentina complementan esta información sobre las estrategias de emigración. Entre los productores rurales de origen español era muy común la existencia de sociedades de hermanos, que solían servir de vehículo para el "rearmado" familiar. El caso más frecuente era que un hermano que se había afincado hacia varios años y que había alcanzado una situación mas o menos consolidada, se asociaba con uno o dos hermanos -o primos, según los casos- que hubieren llegado hacia poco tiempo. El residente "veterano" servia de puente para iniciarlos en las actividades rurales, jugando una vez más el rol de "pionero" que le había tocado en el momento de salir de la aldea. Los indicios de un lado y otro del Atlántico tienden a hacernos pensar que la estrategia de migración paulatina de los

(30) Esta emigración de algunas personas mayores con el objeto de reencontrarse con la familia también lo pudimos recrear a través de las entrevistas que realizamos a descendientes de leoneses. 
miembros de una familia constituyó una practica muy común entre estos emigrantes que veian en el traslado a América una continuidad de sus estrategias de supervivencia. En tal sentido, y como sostiene Reher, la emigración a América fue sólo en parte una respuesta nueva, pues si bien implicaba un desplazamiento espacial mayor, formó parte de una estrategia familiar muy arraigada en las sociedades campesinas europeas (31).

\section{A MODO DE RECAPITULACIÓN}

Comparando nuestros resultados en las sociedades de salida y de llegada, nos encontramos con una increíble complementación. Existe al menos para el caso que hemos podido estudiar con más profundidad, el castellano-leonés, una relación estrecha entre su calificación en el país de origen y el éxito relativo alcanzado por una parte de ellos (los que se transformaron en productores agrarios) en el destino final. Hemos demostrado fehacientemente las posibilidades de acceso a la producción que les cupo a una parte de los emigrantes leoneses que se conectaron con las redes existentes en el sur de Buenos Aires. Una doble coincidencia facilitaba este hecho: las potencialidades de la sociedad receptora y el conocimiento de parte de los campesinos castellano-leoneses tanto del cultivo del cereal, como de las reglas de juego para organizar una explotación bajo arriendo.

En el proceso emigratorio castellano pareciera que se conjugaran dos procesos diferentes y complementarios: por una parte, la emigración fue parte de la respuesta tradicional de las economías campesinas frente a la estricta relación de equilibrio entre crecimiento poblacional y recursos productivos. En este nivel la emigración temporal o de retorno era una práctica natural muy extendida de las familias campesinas para ampliar sus escasos recursos. Pero junto a este proceso tradicional, existió un segundo tipo de emigración que, como hemos visto, fue parte de la respuesta explosiva dada por la población ante la caída de la rentabilidad de la producción agrícola; lo atractivo de este segundo ciclo fue que expulsó en muy pocos años un tipo de mano de obra adulta y cualificada que conformaba buena parte de los responsables de explotaciones. Estos agricultores especializados en el cereal debieron constituir una mano de obra preciosísima

(31) En tal sentido es muy interesante la perspectiva de D. REHER, Familia, población y sociedad en la Provincia de Cuenca, Madrid, CIS. 1988. 
en una Argentina donde el proceso de expansión cerealera se encontraba en pleno desarrollo.

En razón de las características del ciclo migratorio, los castellano-leoneses que se trasladaron a la Argentina no provenían de los sectores mas pauperizados de la sociedad, eran en su mayoría hijos de pequeños propietarios y labradores o labradores ellos mismos, que emigraban más por un afán de mejoramiento material, que por razones de pobreza absoluta. No era que la supervivencia familiar estuviera en peligro inmediato, si así hubiera sido la perspectiva de emigrar "por las vías normales" hubiera sido imposible, no habrían dispuesto de los medios económicos para hacerlo; pero si lo que peligraba era la reproducción para todo el grupo familiar de ciertas posibilidades de vida (sin sobredimensionar las perspectivas que pudiera plantearse un campesino medio de la meseta castellana) y la emigración - como hemos reiterado- era la alternativa mejor para tratar de resguardar y acrecentar la economía familiar.

Este pequeño campesino estaba en condiciones de elegir con mayor libertad el lugar que les of reciera mejores posibilidades económicas: en este caso la próspera Argentina de principios de siglo. Una vez arribado al Río de la Plata, tenía un mayor margen de acción para la búsqueda de un trabajo acorde y que le permitiera ganar más dinero y a su vez evitar una proletarización en América. En tal sentido, para algunos la posibilidad de transformarse en agricultores arrendatarios en la Pampa, debió ser una alternativa interesante, pues con escaso capital inicial y algunos contactos de paisanos para conseguir tierras, en pocos años podía tener interesantes ganancias. Si esta alternativa era muy ambiciosa se podía empezar de abajo, como peón o trabajador especializado, pues las diferencias salariales respecto de su tierra eran muy atractivas. En estos casos -y al menos en el plano de las aspiraciones- la proletarización debió ser considerada como un paso transitorio hacia la búsqueda de una posición mejor. 